\title{
CHEMICAL CONSTITUENTS DERIVED FROM THE CANARIES MARINE SPONGE Myxilla sp.
}

Pere Ferriol Bunyola ${ }^{a}$, Francisco J. Toledo Marante ${ }^{\mathrm{b}, \mathrm{d}, *}$, Juan Francisco Leon Oyola ${ }^{\mathrm{c}}$, Ignacio Brouard Martin ${ }^{\mathrm{c}}$, Rayco Guedes Alonso $^{d}$ and José J. Santana Rodríguez ${ }^{d}$

aDepartamento de Biología, Universidad de Las Islas Baleares, 07122 Palma de Mallorca, Spain

bepartamento de Química, Universidad de Las Palmas de Gran Canaria, 35017 Las Palmas de Gran Canaria, Spain

'Instituto de Productos Naturales y Agrobiología, CSIC, 38206 La Laguna, Tenerife, Spain

dnstituto de Estudios Ambientales y Recursos Naturales (i-UNAT), Universidad de Las Palmas de Gran Canaria, 35017 Las Palmas de Gran Canaria, Spain

Recebido em 10/09/2017; aceito em 21/11/2017; publicado na web em 11/12/2017

\begin{abstract}
Stigmasterols, ceramides, including ceramide-1-phosphates and pyrimidines were identified in an ethanol extract of the marine sponge Myxilla sp. The compounds were identified by MS and 1D- and 2D-NMR techniques. A simple method based on an ultrahigh-performance liquid chromatography coupled with tandem mass spectrometry was developed to investigate the production of the aforementioned ceramides. This is the first report on ceramide-1-phosphates from a marine sponge.
\end{abstract}

Keywords: Myxilla; stigmasterols; ceramides; pyrimidines.

\section{INTRODUCTION}

Marine invertebrates are a rich source of natural compounds that possess various biological activities. The phylum Porifera, Demospongiae class, is the most diverse and species-rich type of these organisms. Among these, the Poecilosclerida Order, Myxillidae Family, Genus Myxilla top the list. In fact, rosacelose, a new anti-HIV polysaccharide was recently isolated from the Myxilla rosacea marine sponge. ${ }^{1}$ Zhukova et al. $^{2}$ also isolated glycolipids from Myxilla incrustans, whose molecular structures contained sphingosine, phytosphingosine, fatty acids and phosphorus. Venkateswarlu et al. ${ }^{3}$ described new ceramides originating from several sponges from the gulf of Mannar. On the basis of these precedents, in this paper we present the chromatographic and spectroscopic study of an ethanolic extract from the Myxilla sp., for which specimens were collected from the Canary Islands. ${ }^{4}$ This study yielded the stigmasterols $\mathbf{1 , 3}, \mathbf{5}$ and $\mathbf{7}$, the ceramides 9-13, the ceramide-1-phosphates 14-22 and the pyrimidines 23-24.

\section{EXPERIMENTAL}

\section{General experimental procedures}

Normal-phase chromatography was carried out on silica gel (Scharlau) with a $0.06-0.2 \mathrm{~mm}$ particle size for the adsorbent and 0.04-0.06 $\mathrm{mm}$ for the stationary phase. The chromatography was performed either at medium pressure (Büchi Chromatography System) or at low pressure with Fluid Metering Inc. motors connected in series with an Ace Glass Inc. column. Normal-phase TLC was performed on silica gel plates $(0.25 \mathrm{~mm}$ diameter, Tracer Analitica) using a combination of hexane, ethyl acetate (EtOAc), chloroform $\left(\mathrm{Cl}_{3} \mathrm{CH}\right)$ and methanol $(\mathrm{MeOH})$ as an eluent, in proportions specified for each case. Reverse-phase TLC was carried out on RP18- $\mathrm{F}_{254}$ plates $\left(0.25 \mathrm{~mm}\right.$, Merck) with the use of $\mathrm{CH}_{3} \mathrm{CN} / \mathrm{CH}_{3} \mathrm{OH} / \mathrm{H}_{2} \mathrm{O}$ (80:18:2) as a mobile phase. In all cases, the spots were revealed by spraying with oleum (4\% sulphuric acid, $80 \%$ acetic acid, $16 \%$ water) and heating at $120{ }^{\circ} \mathrm{C}$ for 20 minutes. ${ }^{1} \mathrm{H}$-, ${ }^{13} \mathrm{C}$-, and $2 \mathrm{D}-\mathrm{NMR}$ experiments were recorded on a Bruker spectrometer, AMX-300

\footnotetext{
*e-mail: franciscojavier.toledo@ulppg.es
}

or AMX-500 models, with standard pulse sequences operating at 300 or $500 \mathrm{MHz}$ in ${ }^{1} \mathrm{H}-\mathrm{NMR}$ spectroscopy and 75 or $125 \mathrm{MHz}$ in ${ }^{13} \mathrm{C}$-NMR spectroscopy. Tetramethylsilane was used as an internal standard for the calibration of the ${ }^{1} \mathrm{H}-\mathrm{NMR}$ spectra and deuterated chloroform $(\delta 77.00) /$ deuterated dimethyl sulfoxide $(\delta 39.70) /$ deuterated pyridine $(\delta$ 149.80) was used for the calibration of the ${ }^{13} \mathrm{C}$-NMR spectra. Electrospray ionization mass spectrometry (ESI-MS) was performed either at low or high resolutions with a common electron impact mass spectrometer (IE) or by fast atom bombardment (FAB). Positive-mode was carried out on a FAB-MS at $70 \mathrm{eV}$ with a FISONS VG Micromass Autospec apparatus with NBA (3-nitrobencylic alcohol) as the matrix. Melting points were stablished using a Gallenkamp apparatus and were left uncorrected.

\section{Animal material}

In the summer of 2006, we started a marine sponge bioprospecting campaign near the effluent pipe of a fish farm, in Castillo del Romeral, Santa Lucía, Gran Canaria island (27 $\left.47^{\prime} 53^{\prime \prime} \mathrm{N} ; 15^{\circ} 26^{\prime} 51^{\prime \prime} \mathrm{W}\right)$, at 5 $m$ depth. As a result of it, specimens of a marine sponge classified as Myxilla sp. were collected. A voucher sample (Por.11) was deposited at the "Colección de Zoología ZCM, Universidad de Las Palmas de Gran Canaria (www.gbif.es)", Canary Islands, as communicated in a conference. $^{4}$

\section{Extraction and isolation}

Fresh sponge (3399 g) was extracted exhaustively with acetone (3 L, x3) and ethanol (3 L, x3). The combined extract $(67,11 \mathrm{~g})$ was chromatographed at medium pressure (Büchi Chromatography System) on silica gel (Scharlau, 0.04-0.06 mm) as the stationary phase. A gradient elution from hexane to EtOAc, then from EtOAc to $\mathrm{Cl}_{3} \mathrm{CH}$, and later still from $\mathrm{Cl}_{3} \mathrm{CH}$ to $\mathrm{MeOH}$ was used (the amount and proportion of each solvent is specified in Table 1S). The $100 \mathrm{~mL}$ fractions collected were monitored by normal-phase TLC on silica gel plates $(0.25 \mathrm{~mm}$ diameter) using a combination of hexane ( $\mathrm{x} \%)$ and EtOAc [(100-x)\%] as eluents and pooled together to obtain three TLC homogeneous fractions, namely: 1) the sterol mixture, 2) the ceramide mixture and 3 ) the pyrimidinic nucleobase mixture. 


\section{The sterol mixture $(1+3+5+7)$}

White amorphous solid; m.p. $277-278{ }^{\circ} \mathrm{C} ;[\alpha]_{\mathrm{D}}^{25^{\circ} \mathrm{C}}=-15.2^{\circ}(\mathrm{c}$ $\left.0.2 ; \mathrm{CHCl}_{3}\right)$. Both values are in agreement with those reported in literature for the $\beta$-sitosterol (m.p. $=277-278{ }^{\circ} \mathrm{C},{ }^{5}[\alpha]_{\mathrm{D}}{ }^{25^{\circ} \mathrm{C}}=-15.2^{\circ}$ (c $\left.0.2 ; \mathrm{CHCl}_{3}\right) \cdot{ }^{6}$ For ${ }^{1} \mathrm{H}$ - and ${ }^{13} \mathrm{C}$-NMR spectra, see Table 2S. ESI-MS $m / z, 414.39,412.39,386.36,368.30,273.28,255.23$; HR-ESI-MS $\mathrm{m} / z, 414.3854$ (calcd for $\mathrm{C}_{29} \mathrm{H}_{50} \mathrm{O} 414.3862$ ); 386.3903 (calcd for $\left.\mathrm{C}_{28} \mathrm{H}_{50} 386.3913\right)$.

\section{The acetate of the sterol mixture $(2+4+6+8)$}

The sterol mixture $(50 \mathrm{mg})$ was dissolved in pyridine $(1 \mathrm{~mL})$ and acetic anhydride was added $(2 \mathrm{~mL})$. After 24 hours stirring at room temperature, $5 \mathrm{~g}$ of crushed ice was added and stirred for 30 minutes. By extraction with diethyl ether, washing with $2 \mathrm{~N} \mathrm{HCl}$ and $10 \%$ $\mathrm{NaHCO}_{3}$, drying on anhydrous $\mathrm{Na}_{2} \mathrm{SO}_{4}$, filtrating and evaporating with a rotary evaporator, a white amorphous solid was obtained. Crystals of this mixture of compounds were obtained from $\mathrm{MeOH}$; for ${ }^{1} \mathrm{H}$ - and ${ }^{13} \mathrm{C}$-NMR spectra, see Table $2 \mathrm{~S}$ and discussion for the lateral chain; ESI-MS $m / z$ 456.38, 442.38; HR-ESI-MS m/z, 456.3976 (calcd for $\mathrm{C}_{31} \mathrm{H}_{52} \mathrm{O}_{2} 456.3967$ ).

\section{The ceramide mixture $(9-13)$}

White amorphous solid; m.p. $87-88^{\circ} \mathrm{C} ;[\alpha]_{\mathrm{D}}{ }^{20^{\circ} \mathrm{C}}=-2.6^{\circ}$ (c 0.945 ; $\left.\mathrm{Cl}_{3} \mathrm{CH}\right)$; TLC, $\mathrm{R}_{\mathrm{f}}=0.60$ in $\mathrm{Cl}_{3} \mathrm{CH}(50 \mathrm{~mL}) / \mathrm{MeOH}(30 \mathrm{~mL}) / \mathrm{AcOH}$ $(8 \mathrm{~mL}) / \mathrm{H}_{2} \mathrm{O}(7 \mathrm{~mL})$ as eluent. ${ }^{1} \mathrm{H}-\mathrm{NMR},\left(\mathrm{Cl}_{3} \mathrm{CD}, 300 \mathrm{MHz}\right) \delta 6.26$ $(1 \mathrm{H}, \mathrm{d}, \mathrm{J}=7.26 \mathrm{~Hz}), 5.77\left(1 \mathrm{H}, \mathrm{dt}, \mathrm{J}_{4,5}=15.3, \mathrm{~J}_{5,6}=6.6 \mathrm{~Hz}\right), 5.53(1 \mathrm{H}$, $\left.\mathrm{dd}, \mathrm{J}_{3,4}=6.4 \mathrm{~Hz}, \mathrm{~J}_{4,5}=15.3 \mathrm{~Hz}\right), 3.60-4.31(4 \mathrm{H}, \mathrm{m}, 1 \mathrm{a}-\mathrm{H}, 1 \mathrm{~b}-\mathrm{H}, 2-\mathrm{H}$, 3-H), $2.80\left(1 \mathrm{H}\right.$, br s, OH), $2.23\left(2 \mathrm{H}, \mathrm{t}, \mathrm{J}=7.6 \mathrm{~Hz}, 2^{\prime}-\mathrm{H}\right), 2.04(2 \mathrm{H}$, m, 6-H), $1.66\left(1 \mathrm{H}\right.$, br s, OH), $1.63\left(2 \mathrm{H}, \mathrm{m}, 3^{\prime}-\mathrm{H}\right), 1.25\left(34 \mathrm{H}, \mathrm{CH}_{2}\right)$, $1.22\left(22 \mathrm{H}, \mathrm{CH}_{2}\right), 0.88\left(3 \mathrm{H}, \mathrm{t}, \mathrm{J}=6.6 \mathrm{~Hz}, \mathrm{CH}_{3}\right), 0.87(3 \mathrm{H}, \mathrm{t}, \mathrm{J}=6.6$ $\left.\mathrm{Hz}, \mathrm{CH}_{3}\right) .{ }^{13} \mathrm{C}-\mathrm{NMR}\left(\mathrm{Cl}_{3} \mathrm{CD}, 75 \mathrm{MHz}\right) \delta 173.95,134.31,128.76$, 74.66, 62.49, 54.46, 36.84, 32.28, 31.92, 29.69, 29.36, 25.75, 22.68, 14.11. ${ }^{13} \mathrm{C}-\mathrm{NMR}\left(\mathrm{Py}_{-} \mathrm{D}_{5}, 125 \mathrm{MHz}\right) \delta 175.44,134.36,134.24,75.29$, 64.14, 58.85, 38.87, 34.12, 34.10, 32.00, 31.98, 31.90, 31.87, 31.84, $31.76,31.71,31.61,31.59,31.55,28.42,24.92,16.26$. ESI-MS $m / z$ 362.31 (3.0\%), 350.31 (3.2\%), 336.29 (5.4\%), 323.28 (3.46\%). HR-ESI-MS $\mathrm{m} / \mathrm{z} 672.6302\left([\mathrm{M}+\mathrm{Na}]^{+}, \mathrm{C}_{24}\right.$-ceramide) (calcd for $\mathrm{C}_{42} \mathrm{H}_{83} \mathrm{NO}_{3} \mathrm{Na}$ 672.6302); 658.6120 ([M+Na $]^{+}, \mathrm{C}_{23}$-ceramide) (calcd for $\mathrm{C}_{41} \mathrm{H}_{81} \mathrm{NO}_{3} \mathrm{Na}$ 658.6114); $644.6007\left([\mathrm{M}+\mathrm{Na}]^{+}, \mathrm{C}_{22}\right.$-ceramide) (calcd for $\left.\mathrm{C}_{40} \mathrm{H}_{79} \mathrm{NO}_{3} \mathrm{Na} 644.5958\right) ; 630.5812\left([\mathrm{M}+\mathrm{Na}]^{+}, \mathrm{C}_{21^{-}}\right.$ ceramide) (calcd for $\left.\mathrm{C}_{39} \mathrm{H}_{77} \mathrm{NO}_{3} \mathrm{Na} 630.5812\right) ; 616.5662\left([\mathrm{M}+\mathrm{Na}]^{+}\right.$, $\mathrm{C}_{20}$-ceramide) (calcd for $\mathrm{C}_{38} \mathrm{H}_{75} \mathrm{NO}_{3} \mathrm{Na} 616.5645$ ).

\section{Identification of the ceramide-1-phosphates (14-22) in the ceramide mixture}

These minor metabolites were detected by high-resolution mass spectrometry (HRMS) and an ultra high-pressure liquid chromatography tandem mass spectrometry technique (UHPLC-MS/MS).

\section{Reagents used in the UHPLC-MS method}

Stock solutions containing $1000 \mathrm{mg} \mathrm{L}^{-1}$ of ceramide-1-phosphates mixture were prepared by dissolving the mixture in tetrahydrofuran (Fischer Chemical, Madrid, Spain). The solutions were stored in glass-stoppered bottles at $-20{ }^{\circ} \mathrm{C}$ before use. Working solutions were prepared daily using acetonitrile as solvent (Panreac Química, Barcelona, Spain). LC-MS grade methanol, LC-MS water as well as formic acid, used to adjust the $\mathrm{pH}$ of the mobile phases, were obtained from Panreac Química (Barcelona, Spain).

\section{Instrumentation used in the UHPLC-MS method}

The mass spectrum was performed in a UHPLC-MS/MS system from Waters (Madrid, Spain), with a Quaternary Solvent Manager (QSM) used to load samples and wash and recondition the analytical column, a $2777 \mathrm{C}$ sample manager equipped with a $25 \mu \mathrm{L}$ syringe, a tray to hold $2 \mathrm{~mL}$ vials, and an ACQUITY triple quadrupole (TQD) mass spectrometer with an electrospray ionization (ESI) interface. All Waters components (Madrid, Spain) were controlled using the MassLynx Mass Spectrometry Software. Electrospray ionization parameters were fixed as follows: the capillary voltage was $4 \mathrm{kV}$ in positive mode, the cone voltage was $80 \mathrm{~V}$, the source temperature was $120{ }^{\circ} \mathrm{C}$, the desolvation temperature was 450 ${ }^{\circ} \mathrm{C}$, and the desolvation gas flow rate was $1000 \mathrm{~L} \mathrm{hour}^{-1}$. Nitrogen was used as the desolvation gas and argon was employed as the collision gas.

\section{Chromatographic conditions in the UHPLC-MS method}

For the chromatographic separation, the analytical column was a $50 \mathrm{~mm} \times 2.1 \mathrm{~mm}$ ACQUITY UHPLC BEH Waters $\mathrm{C}_{18}$ with a particle size of $1.7 \mu \mathrm{m}$ (Waters Chromatography, Barcelona, Spain) operating at a temperature of $30{ }^{\circ} \mathrm{C}$. Analytes separation was carried out in isocratic mode, 95:5, using water with $5 \mathrm{mM}$ formic acid (A) and methanol (B). The sample volume injected was $10 \mu \mathrm{L}$.

\section{The pyridinic nucleobase mixture $(23+24)$}

Two heterocyclic compounds appear mixed as a white amorphous solid. After integration of the ${ }^{1} \mathrm{H}-\mathrm{NMR}$ spectrum of the mixture, the composition was deduced to be $\mathrm{C}_{\text {uracil }} / \mathrm{C}_{\text {thymine }}=1.1$.

Thymine (23). Amorphous white solid. ${ }^{1} \mathrm{H}-\mathrm{NMR}$ (DMSO- $\mathrm{D}_{6}$, $300 \mathrm{MHz}) \delta 11.02(1 \mathrm{H}$, br s), $10.63(1 \mathrm{H}$, br s), $7.26(1 \mathrm{H}$, br s $), 1.73$ $(3 \mathrm{H}, \mathrm{d}, J=0.6 \mathrm{~Hz}) .{ }^{13} \mathrm{C}-\mathrm{NMR}$ (DMSO-D $\left.6,75 \mathrm{MHz}\right) \delta 165.2,151.7$, 138.0, 107.9, 12.0.

Uracil (24). Amorphous white solid. ${ }^{1} \mathrm{H}-\mathrm{NMR}$ (DMSO-D $300 \mathrm{MHz}) \delta 11.00(1 \mathrm{H}$, br s), $11.00(1 \mathrm{H}$, br s), $7.40(1 \mathrm{H}, \mathrm{d}$, $J=7.5 \mathrm{~Hz}), 5.46(1 \mathrm{H}, \mathrm{d}, J=7.5 \mathrm{~Hz}) .{ }^{13} \mathrm{C}-\mathrm{NMR}\left(\mathrm{DMSO}_{-} \mathrm{D}_{6}, 75 \mathrm{MHz}\right)$ $\delta 164.7,151.7,142.5,100.4$.

\section{RESULTS AND DISCUSSION}

\section{The sterols}

The fractions that contained sterols were eluted with a mixture of hexane/EtOAc 80:20, and were repeatedly chromatographied, thereby allowing the identification of the following compounds: stigmast-5-en-3 $\beta$-ol ( $\beta$-sitosterol) $(\mathbf{1}, 75 \%)$, stigmast-5,25-dien-3 $\beta$-ol $(\mathbf{3}, 7 \%)$, stigmast-5,24(25)-dien-3 $\beta$-ol $(\mathbf{5}, 2 \%)$ and stigmast-5,23dien-3 $\beta$-ol $(7,16 \%)$. The high resolution mass spectrum (HRMS) showed a peak at $\mathrm{m} / \mathrm{z} 414.3854$ corresponding to the molecular ion which in turn corresponds to the molecular formula $\mathrm{C}_{29} \mathrm{H}_{50} \mathrm{O}$. The presence of secondary products with one unsaturation on the side chain is demonstrated by the observation of a molecular ion at $m / z, 412\left(\mathrm{C}_{29} \mathrm{H}_{48} \mathrm{O}\right)$. On the basis of the intensity of the molecular peaks -414 vs 412 - we can deduce that the unsaturated side chain compounds are present at a final concentration of $25 \%$. The ${ }^{1} \mathrm{H}-\mathrm{NMR}$ spectrum showed a signal at $\delta 5.35(1 \mathrm{H}$, overlapped double doublets) characteristic of a double bond between the carbons 5 and 6 of the four sterols with the same skeleton as $\beta$-sitosterol. A signal at $\delta 5.16$ in the form of a deformed triplet revealed the minor presence $(16 \%)$ of the regioisomer stigmast-5,23-dien-3 $\beta$-ol (7). Two broad singlets at $\delta 4.71$ and $\delta 4.67$ (both in a ratio 1:1) revealed the olefinic 
methylene of stigmast-5,25-dien-3 $\beta$-ol (3). The ${ }^{13} \mathrm{C}$-NMR spectrum of the aforementioned mixture showed the presence of peaks that can be assigned to all carbons of the steroidal nucleus present in the four steroids (Table $2 \mathrm{~S}$ ). The signals that give evidence of the four side chains of the mixture were observed, giving the following results: signals assignable to C25 and C26 were emitted by stigmast-5,25dien-3 $\beta$-ol 3 ( $\delta 145.6$ and 116.4 respectively), to C23 and C24 from stigmast-5,23-dien-3 $\beta$-ol 7 ( $\delta 135.9$ and 131.7 respectively) and to $\mathrm{C} 24$ and $\mathrm{C} 25$ from stigmast-5,24(25)-dien-3ß-ol $\mathbf{5}$ ( $\delta 124.0$ and 126.1 respectively).

On the other hand, the mixture of sterols was acetylated as usual to give the corresponding mixture of acetates, stigmast-5-en-3 $\beta$-ol acetate $(\mathbf{2}, 75 \%)$, stigmast-5,25-dien-3 $\beta$-ol acetate $(\mathbf{4}, 7 \%)$, stigmast-

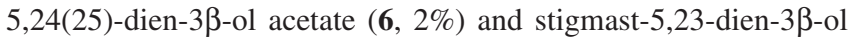
acetate $(\mathbf{8}, 16 \%)$. The ${ }^{1} \mathrm{H}-\mathrm{NMR}$ spectrum of this mixture of acetates revealed a sole steroid skeleton and also shows up the different side chains of the mixture. Therefore, a triplet centered at $\delta 5.16$ corresponds to stigmast-5,23-dien-3 $\beta$-ol acetate $(\mathbf{8})$ and two signals at $\delta 4.71$ and $\delta 4.65$ revealed the methylene of the stigmast-5,25dien-3 $\beta$-ol acetate (4).

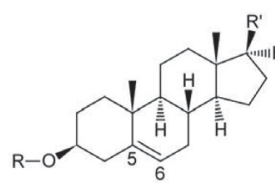

$\mathrm{R}^{\prime}=$<smiles>CC[C@@H](CCC(C)C)C(C)C</smiles>

(75\%)

$\mathrm{R}=\mathrm{H}, 1$
$\mathrm{R}=\mathrm{CH}_{3} \mathrm{CO}, 2$
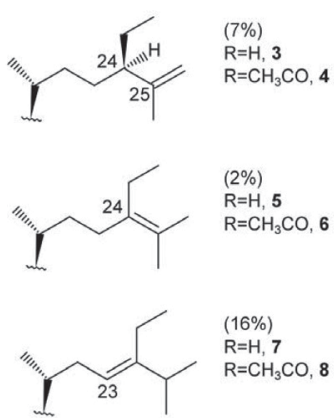

Figure 1. Sterols identified in Myxilla sp. $(\mathbf{1 , 3 , 5 , 7 )}$ and their acetates $(\mathbf{2 , 4 , 6 , 8 )}$

Again, the integral curves of these signals are consistent with the proportion assigned in Figure 1. In the ${ }^{13} \mathrm{C}-\mathrm{NMR}$ spectrum (Table $2 \mathrm{~S}$ ) the expected signals were also found, including the minority signals in the olefinic zone of the spectrum $(\delta$ 116-146) produced by the unsaturated stigmasterol acetates $(\mathbf{4}, \mathbf{6}$ and $\mathbf{8})$.

\section{The ceramides}

The ceramides mixture (Figure 2) is a white solid, and homogeneous by TLC. The physical constants of the mixture are: m.p. $87-88^{\circ} \mathrm{C},[\alpha]_{\mathrm{D}}{ }^{20^{\circ} \mathrm{C}}=-2.6\left(\mathrm{Cl}_{3} \mathrm{CH}, \mathrm{c} 0.945\right)$. Both chromatographic $\left(\mathrm{R}_{\mathrm{f}}\right)$ and spectroscopic data $\left({ }^{1} \mathrm{H}\right.$ and ${ }^{13} \mathrm{C}$ NMR spectra) revealed the typical characteristics of ceramides, consistent with literature. ${ }^{7}$ That is, erythro configuration $(2 S, 3 R)$ and a 4,5-trans double bond in the base component, the latter linked to long-chain fatty acids (more than 16 carbons) via an amide bond. Carbons $2 S$ and $3 R$ cause shifts in the ${ }^{13} \mathrm{C}$ NMR spectrum at $\delta 54.46$ and 74.66 respectively, and the trans double bond yields a coupling constant of $15.3 \mathrm{~Hz}$ in the ${ }^{1} \mathrm{H}-\mathrm{NMR}$ spectrum for the two vinylic protons.
The chemical structures were confirmed by HRMS, DEPT135, DEPT-90 and two-dimensional nuclear magnetic resonance spectroscopy (COSY, NOESY, HSQC and HMBC).

Several nitrogenous fragments were detected in the mass spectrum at $m / z 362.31\left(\mathrm{C}_{23} \mathrm{H}_{40} \mathrm{NO}_{2}, 3.0 \%\right), 350.31\left(\mathrm{C}_{22} \mathrm{H}_{40} \mathrm{NO}_{2}, 3.2 \%\right), 336.29$ $\left(\mathrm{C}_{21} \mathrm{H}_{38} \mathrm{NO}_{2}, 5.4 \%\right), 323.28\left(\mathrm{C}_{20} \mathrm{H}_{37} \mathrm{NO}_{2}, 3.46 \%\right)$ and the molecular ions as sodium adducts at $\mathrm{m} / z, 672.6302\left([\mathrm{M}+\mathrm{Na}]^{+}, \mathrm{C}_{24}\right.$-ceramide, $31.79 \%), 658.6120\left([\mathrm{M}+\mathrm{Na}]^{+}, \mathrm{C}_{23}\right.$-ceramide, $\left.11.52 \%\right), 644.6007$ $\left([\mathrm{M}+\mathrm{Na}]^{+}, \mathrm{C}_{22}\right.$-ceramide, $\left.40.25 \%\right), 630.5812\left([\mathrm{M}+\mathrm{Na}]^{+}, \mathrm{C}_{21}\right.$-ceramide, $7.97 \%)$ and $616.5662\left([\mathrm{M}+\mathrm{Na}]^{+}, \mathrm{C}_{20}\right.$-ceramide, $\left.8.47 \%\right)$.

In the DEPT-135 experiment, the four methines and two methyls (positive signals) were separated from rest of methylenes (negative signals). C1 is included in the latter. In the DEPT-90 experiment only the four methines were separated (positive signals). The COSY spectrum showed the following correlations: $(2, \mathrm{NH}) ;(3,4) ;(5,6)$; $(1 \mathrm{a}, 1 \mathrm{~b}) ;(6,7) ;\left(2^{\prime}, 3^{\prime}\right)$ and $\left(3^{\prime}, 4^{\prime}\right)$, among others. In the NOESY spectrum the correlation between hydroxyl group protons in $\mathrm{C}-1$ and $\mathrm{C}-3$ is to be highlighted. The HSQC spectrum provides the correlation between proton and their attached carbon $\left(\mathrm{H}_{1 \mathrm{a}}\right.$ and $\mathrm{H}_{1 \mathrm{~b}}$ to $\mathrm{C}_{1}, \mathrm{H}_{2}$ to $\mathrm{C}_{2}$, etc.), whereas in the HMBC spectrum each proton is correlated to carbons that are separated by two or three bonds $\left(\mathrm{H}_{3}\right.$ to $\mathrm{C}_{1}, \mathrm{C}_{2}$, $\mathrm{C}_{4}$ and $\mathrm{C}_{5}$, etc).<smiles>CCCCCCCCCCCCC/C=C/C(O)[C@H](C)N(C)C(=O)C(CCC(C)C)OP</smiles>

Figure 2. Ceramides identified in Myxilla sp.

\section{The ceramide-1-phosphates}

The ceramide-1-phosphates mixture was detected as an impurity of the previous ceramides mixture. The high-resolution mass spectrum obtained showed different phosphorated fragments $[\mathrm{m} / \mathrm{z} 490.3287$ $\left(\mathrm{C}_{25} \mathrm{H}_{49} \mathrm{NO}_{6} \mathrm{P}, 4.5 \%\right.$, Figure 4), $476.3143\left(\mathrm{C}_{24} \mathrm{H}_{47} \mathrm{NO}_{6} \mathrm{P}, 2.5 \%\right)$, $472.3176\left(\mathrm{C}_{25} \mathrm{H}_{47} \mathrm{NO}_{5} \mathrm{P}, 15.7 \%\right)$ and $462.2969\left(\mathrm{C}_{23} \mathrm{H}_{45} \mathrm{NO}_{6} \mathrm{P}, 8.1 \%\right.$, Figure 4)]. On the other hand, the molecular ions of the compounds indicated in Figure 3, from $\mathrm{n}=11$ (ceramide-1-phosphate- $\mathrm{C}_{16}$ or Cer1PC $_{16}, \mathbf{1 4}$ ) to $\mathrm{n}=19$ (ceramide-1-phosphate- $\mathrm{C}_{24}$ or Cer1PC ${ }_{24}, \mathbf{2 2}$ ) were detected by direct injection in the ultra-high performance liquid chromatography mass spectrometer (UHPLC-MS). The percentage composition of the mixture was calculated using the relative intensities of the molecular ions, and gave the highest percentage for ceramide-1-phosphate-C18 or Cer1PC 18 which is made up of stearic acid.

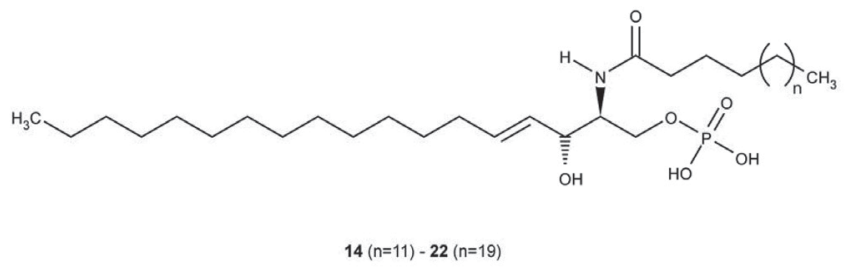

Figure 3. Ceramide-1-phosphates identified in Myxilla sp.

The ceramide-1-phosphates spectrum was obtained by the direct injection of a $1 \mathrm{mg} \mathrm{L}^{-1}$ ceramides mixture solution into the detector at a flow rate of $10 \mu \mathrm{L}$ minute ${ }^{-1}$. The spectra showed nine molecular ions belonging to the positive ionized ceramide-1-phosphates. Each 


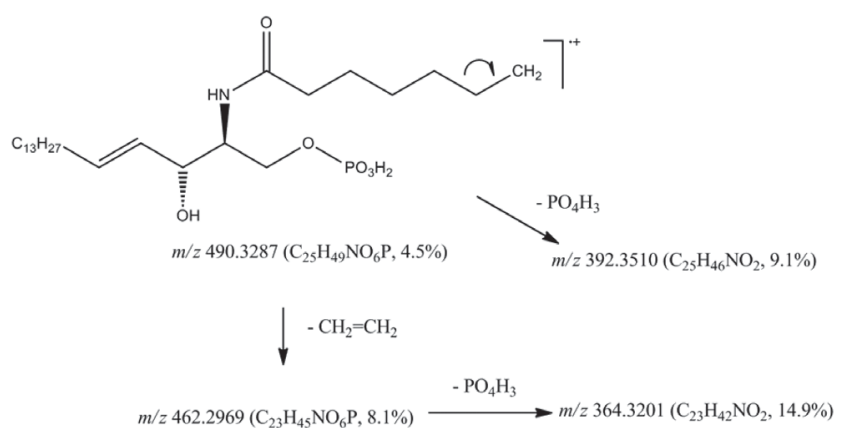

Figure 4. Fragmentation schema of the mixture of ceramide-1-phosphates isolated from Myxilla sp. observed in high-resolution mass spectrum

ion increased its mass by 14 units with the addition of each new methylene group. The ion with the largest intensity was $\mathrm{m} / \mathrm{z}=644.60$ corresponding to $\left(\mathrm{Cer}_{1} \mathrm{PC}_{18}-\mathrm{H}\right)^{+}$.

After the mass spectrum was obtained, a solution of ceramide1-phosphates was injected in the UHPLC-MS system to obtain the chromatographic separation of the ceramide-1-phosphates. However, the compounds could not be chromatographically separated because of the similarity of their structures, as it can be observed in Figure 5. The detection was performed using the first quadrupole because no stable "daughter ion" was obtained in the fragmentation of the "parent ions".

Sponges of genus Myxilla are emerging as a source of natural products with the carbon skeleton of sphingosine. Sphingosine-1phosphate has been described in Myxilla incrustans. ${ }^{8}$ Apparently, ceramides and ceramide-1-phosphates have antagonistic functions, and a correct balance between the concentrations of both metabolites is needed for cell and tissue homeostasis. The mixture of ceramide-1-phosphates is made up of metabolites involved in the sphingomyelin cycle, as these are sphingolipids that are analogous to phosphatidic acid. These metabolites are formed from the ceramides thanks to the action of a specific ceramide kinase, which is related to but distinct from the sphingosine kinase that synthesizes sphingosine-1-phosphate.

\section{The pyrimidinic bases}

The more polar fractions of the extract yielded two nucleobases, thymine (23) and uracil (24). Both bases appear mixed as a white amorphous solid, which spontaneously precipitates from hexane/ EtOAc. With the integration of the ${ }^{1} \mathrm{H}-\mathrm{NMR}$ spectrum of the mixture, the composition was deduced to be $\mathrm{C}_{\text {uracil }} / \mathrm{C}_{\text {thymine }}=1$.1. After repeated chromatographies on the silica gel at low pressure, a sample of pure thymine was obtained. This product provided spectroscopic data in agreement with literature reports. ${ }^{9}$ With its substraction, from the spectrum of the mixture, we can deduce the presence of spectrum of uracil, also in agreement with the literature. ${ }^{9}$

In past studies these bases were isolated from marine sponges from Indonesia. ${ }^{10}$ Nevertheless, this is the first time that they have been described for the genus Myxilla.

\section{CONCLUSIONS}

The chemical study of an ethanolic extract of the Myxilla sp. sponge by chromatographic and spectroscopic techniques, afforded natural products of the type of stigmasterol, ceramides, ceramide-1phosphates and pyrimidines. This study reports for the first time the isolation of ceramide-1-phosphates from a marine sponge. A facile method based on ultra-high performance liquid chromatography
Table 1. Parent ions of the mixture of ceramide-1-phosphates isolated from Myxilla sp. detected by direct injection into the UPLC-MS system. The relative intensities give the relative amounts (percentage) of each compound in the mixture.

\begin{tabular}{|c|c|c|}
\hline $\begin{array}{l}\text { Observed ion and } \\
\text { formula }\end{array}$ & $\begin{array}{c}\text { Concentration } \\
(\% \mathrm{w} / \mathrm{w})\end{array}$ & $\begin{array}{c}\text { Ceramide } \\
\text { (n value in Figure 3) }\end{array}$ \\
\hline $\begin{array}{c}616.57\left(\mathrm{M}-1^{+}\right) \\
\mathrm{C}_{34} \mathrm{H}_{67} \mathrm{NO}_{6} \mathrm{P} \\
617.58\left(\mathrm{M}^{+}\right) \\
\mathrm{C}_{34} \mathrm{H}_{68} \mathrm{NO}_{6} \mathrm{P} \\
\end{array}$ & 12.96 & $\operatorname{Cer1PC}_{16}(\mathbf{1 4}, \mathrm{n}=11)$ \\
\hline $\begin{array}{c}630.58\left(\mathrm{M}-1^{+}\right) \\
\mathrm{C}_{35} \mathrm{H}_{69} \mathrm{NO}_{6} \mathrm{P} \\
631.59\left(\mathrm{M}^{+}\right) \\
\mathrm{C}_{35} \mathrm{H}_{70} \mathrm{NO}_{6} \mathrm{P}\end{array}$ & 6.21 & $\operatorname{Cer} 1 \mathrm{PC}_{17}(\mathbf{1 5}, \mathrm{n}=12)$ \\
\hline $\begin{array}{c}644.60\left({\left.\mathrm{M}-1^{+}\right)} \mathrm{C}_{36} \mathrm{H}_{71} \mathrm{NO}_{6} \mathrm{P}\right. \\
645.60\left(\mathrm{M}^{+}\right) \\
\mathrm{C}_{36} \mathrm{H}_{72} \mathrm{NO}_{6} \mathrm{P}\end{array}$ & 28.34 & $\operatorname{Cer}_{1 C_{18}}(\mathbf{1 6}, \mathrm{n}=13)$ \\
\hline $\begin{array}{c}658.61\left(\mathrm{M}-1^{+}\right) \\
\mathrm{C}_{37} \mathrm{H}_{73} \mathrm{NO}_{6} \mathrm{P} \\
659.62\left(\mathrm{M}^{+}\right) \\
\mathrm{C}_{37} \mathrm{H}_{74} \mathrm{NO}_{6} \mathrm{P}\end{array}$ & 13.90 & $\operatorname{Cer} 1 P C_{19}(\mathbf{1 7}, \mathrm{n}=14)$ \\
\hline $\begin{array}{c}672.63\left(\mathrm{M}-1^{+}\right) \\
\mathrm{C}_{38} \mathrm{H}_{75} \mathrm{NO}_{6} \mathrm{P} \\
673.63\left(\mathrm{M}^{+}\right) \\
\mathrm{C}_{38} \mathrm{H}_{76} \mathrm{NO}_{6} \mathrm{P}\end{array}$ & 21.05 & \left.${\operatorname{Cer} 1 P C_{20}}_{(18}, \mathrm{n}=15\right)$ \\
\hline $\begin{array}{c}686.64\left(\mathrm{M}-1^{+}\right) \\
\mathrm{C}_{39} \mathrm{H}_{77} \mathrm{NO}_{6} \mathrm{P} \\
687.65\left(\mathrm{M}^{+}\right) \\
\mathrm{C}_{39} \mathrm{H}_{78} \mathrm{NO}_{6} \mathrm{P} \\
\end{array}$ & 9.18 & $\operatorname{Cer1PC}_{21}(\mathbf{1 9}, \mathrm{n}=16)$ \\
\hline $\begin{array}{c}700.56\left(\mathrm{M}-1^{+}\right) \\
\mathrm{C}_{40} \mathrm{H}_{79} \mathrm{NO}_{6} \mathrm{P} \\
701.57\left(\mathrm{M}^{+}\right) \\
\mathrm{C}_{40} \mathrm{H}_{80} \mathrm{NO}_{6} \mathrm{P}\end{array}$ & 3.51 & $\operatorname{Cer}_{1 P C}{ }_{22}(\mathbf{2 0}, \mathrm{n}=17)$ \\
\hline $\begin{array}{c}714.58\left(\mathrm{M}-1^{+}\right) \\
\mathrm{C}_{41} \mathrm{H}_{81} \mathrm{NO}_{6} \mathrm{P} \\
715.59\left(\mathrm{M}^{+}\right) \\
\mathrm{C}_{41} \mathrm{H}_{82} \mathrm{NO}_{6} \mathrm{P}\end{array}$ & 0.81 & $\operatorname{Cer} 1 P C_{23}(\mathbf{2 1}, \mathrm{n}=18)$ \\
\hline $\begin{array}{c}728.60\left(\mathrm{M}-1^{+}\right) \\
\mathrm{C}_{42} \mathrm{H}_{83} \mathrm{NO}_{6} \mathrm{P} \\
729.60\left(\mathrm{M}^{+}\right) \\
\mathrm{C}_{42} \mathrm{H}_{84} \mathrm{NO}_{6} \mathrm{P}\end{array}$ & 4.05 & $\operatorname{Cer} 1 P C_{24}(\mathbf{2 2}, \mathrm{n}=19)$ \\
\hline
\end{tabular}

coupled with tandem mass spectrometry (UHPLC-MS/MS) has been established in order to investigate the production of aforementioned ceramides in the future.

\section{SUPPLEMENTARY MATERIAL}

A photograph of the sponge Myxilla sp. and select ${ }^{1} \mathrm{H}-\mathrm{NMR}$, ${ }^{13} \mathrm{C}-\mathrm{NMR}, \mathrm{DEPT}, \mathrm{COSY}$, NOESY, HSQC, HMBC and MS spectra of the compounds identified (1-24) can be seen at http://quimicanova. sbq.org.br, in a free-access PDF file. Further spectroscopy dates are available upon request from the authors.

\section{ACKNOWLEDGEMENTS}

The authors would like to thank the Canary government (Agencia Canaria de Investigación, Innovación y Sociedad de la Información, 

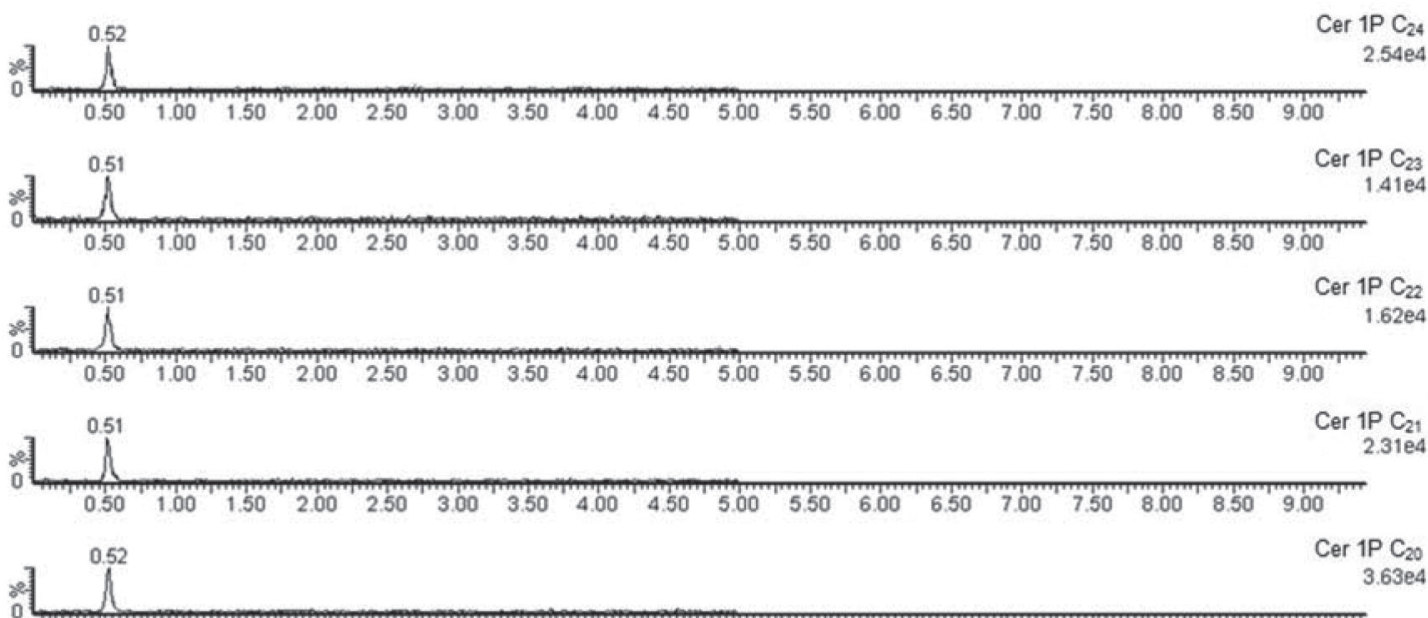

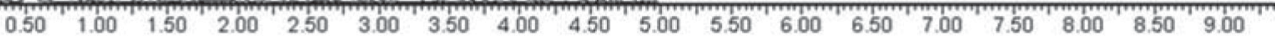

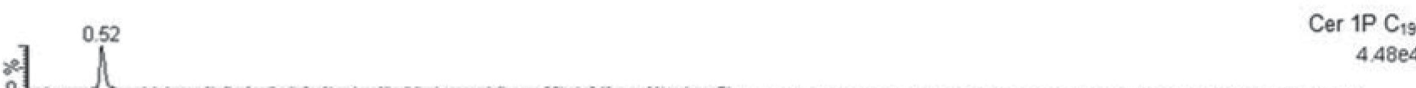

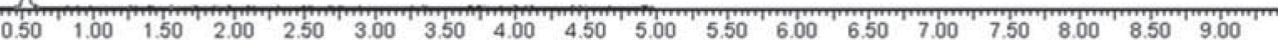

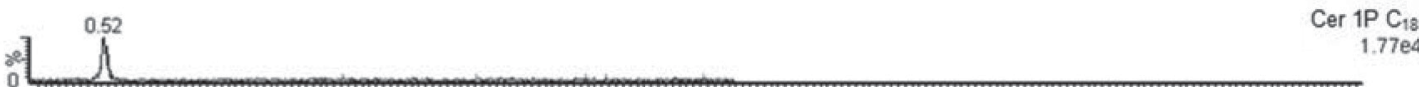

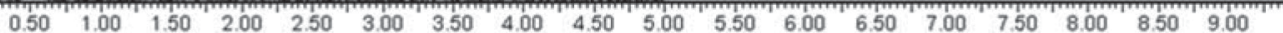

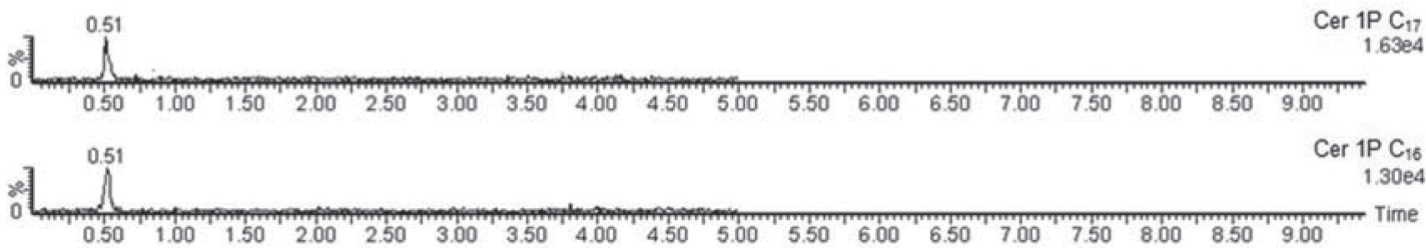

Figure 5. Chromatograms of the ceramide-1-phosphates mixture obtained by UHPLC-MS

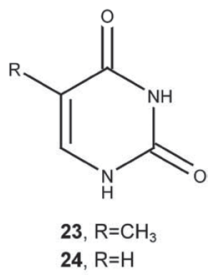

Figure 6. Structures of thymine (23) and uracil (24)

ACIISI) for the PhD fellowship granted to Pere Ferriol, and the financial support given to the project SI-697 (ULPAPD-08/01-5).

\section{REFERENCES}

1. Cimino, P.; Bifulco, G.; Casapullo, A.; Bruno, I.; Gomez-Paloma, L.; Riccio, R.; Carbohydr. Res. 2001, 334, 39.

2. Zhukova, I. G.; Smirnova, G. P.; Vaskovskii, V. E.; Kostetskii, E. Y.; Bogdanovskaya, T. A.; Khim. Biokhim. Uglevodov., Mater. Vses. Konf., 4th 1969, 151 (CA 74:20770).

3. Venkateswarlu, Y.; Reddy, N. S.; Ramesh, P.; Rao, M. R.; Ram, T. S.; Indian J. Chem., Sect. B: Org. Chem. Incl. Med. Chem. 1998, 37B, 1264.

4. Ferriol, P.; Cristobo, J.; Ríos, P.; XV Simposio Ibérico de Estudios de Biología Marina, Funchal, Madeira, Portugal, 2008.

5. Kim, D. K.; Lim, J. P.; Kim, J. W.; Park, H. W.; Eun, J. S.; Arch. Pharmacal Res. 2005, 28, 39.

6. Holzbach, J. C.; Lopes, L. M. X.; Molecules 2010, 15, 9462.

7. Du, W.; Kulkarni, S. S.; Gervay-Hague, J.; Chem. Commun. (Cambridge, U. K.) 2007, 23, 2336.

8. Kochetkov, N. K.; Vas'kovskii, V. E.; Zhukova, I. G.; Smirnova, G. P.; Kostetskii, E. Y.; Doklady Akademii Nauk SSSR 1967, 173, 1448. (CA 67:96996).

9. Xu, S.; Yang, K.; Guo, S.; Liu, Y. Tianran Chanwu Yanjiu Yu Kaifa 2003, 15, 109. (CA 140:335888).

10. Karumanchi, V. R.; Bernard, D. S.; Andrew, D. M.; Raymond, F. S.; Babu, L. T.; Mark, T. H.; J. Nat. Prod. 2003, 66, 823. 